\title{
Are pregnancy-associated plasma protein-A (PAPP-A) and CA 125 measurements after IVF-ET possible predictors of early pregnancy wastage?
}

\author{
Paul Bischof ${ }^{1}$, Thérèse M.Mignot ${ }^{2}$ and Lise Cédard ${ }^{2}$ \\ Department of Obstetrics and Gynaecology, University of Geneva, \\ Switzerland and ${ }^{2}$ U. 166 INSERM, Maternité Baudelocque, Paris, \\ France \\ 'To whom correspondence should be addressed
}

Pregnancy-associated plasma protein-A (PAPP-A), a macromolecular glycoprotein of placental origin, was reported to be depressed in established ectopic pregnancies. CA 125 is a known marker for ovarian cancer found to be elevated during the first trimester of pregnancy and in women with pelvic inflammatory disease. The present study investigated the usefulness of these parameters to predict the outcome of pregnancy in asymptomatic patients with a positive pregnancy test after in-vitro fertilization and embryo transfer (IVF-ET). Blood samples $(n=159)$ were obtained at different periods of time post-ET from 39 women, 21 of whom experienced a normal pregnancy, 12 had an intrauterine abortion and six had an ectopic pregnancy. PAPP-A and CA 125 were measured by radioimmunoassays. From day 30 onwards in normal pregnancies, PAPP-A was significantly increased over non-pregnant controls. In the spontaneous abortion group, the levels of PAPP-A were significantly lower than in normal pregnancy but higher than in non-pregnant controls. In ectopic pregnancy, PAPP-A remained at the level of nonpregnant controls throughout the entire observation period. CA 125 was significantly increased in all types of pregancy. However, in two cases of hyperstimulation followed by a normal pregancy and in four cases of ectopic pregnancy with signs of peritoneal irritation (hydrosalpinx, ruptured ectopic or salpingitis) the levels of CA 125 were $15-50$ times higher than in normal pregnancies. PAPP-A levels $<10$ th percentile, measured after $\mathbf{3 0}$ days post-ET, were an excellent diagnostic parameter for ectopic pregnancy or intrauterine abortion with a sensitivity of $87.5 \%$ and a predictive value of disease of 100\%. In contrast, CA 125 determinations had no diagnostic value and were only indicative of peritoneal inflammation in either normal or pathological pregnancies. It is concluded that PAPP-A is a good parameter by which to monitor postimplantation viability of embryos in IVF-ET patients. Key words: PAPP-A/CA 125/early pregnancy/IVF-ET

\section{Introduction}

Pregnancy-associated plasma protein-A (PAPP-A) is a trophoblastic, macromolecular glycoprotein $\left(M_{r} 800000\right)$ produced in increasing concentrations into the maternal circulation as pregnancy advances (Folkersen et al., 1981; Bischof et al., 1982). The biological function of PAPP-A is unknown so far, but Sinosich et al. (1982) reported that PAPP-A is a specific inhibitor of human granulocyte elastase. Several clinical studies have investigated the usefulness of PAPP-A measurements during pregnancy (Stabile et al., 1988). In first-trimester pregnancies with an ultrasonically proven live fetus, low PAPP-A levels had a $49 \%$ predictive value of fetal demise with a sensitivity of $89 \%$ (Westergaard, 1987). In ectopic pregnancies, most authors found very depressed ( $<10$ th centile) or even unmeasurable concentrations of PAPP-A (Grudzinskas et al., 1984; Sjöberg, 1987; Tornehave et al., 1987) whereas in a similar study with a different design, we found only slightly depressed PAPP-A levels (Bischof et al., 1983).

CA 125 is an antigenic determinant defined by a monoclonal antibody (OC 125) raised against an ovarian carcinoma cell line (Bast $e t$ al., 1981). The structure and function of CA 125 are unknown. CA 125 appears to be the most useful marker for ovarian carcinoma with a reported sensitivity of $>80 \%$ and a concordance with the disease status of $93 \%$ (Bast et al., 1983; Brioschi et al., 1987). During early preganncy, high CA 125 levels were detected during the first trimester but not thereafter (Niloff et al., 1984; Seki et al., 1986).

Since CA 125 has been localized immunohistochemically in mesothelial cells of the peritoneum (Kabawat et al., 1983) and since CA 125 is elevated in pelvic inflammatory disease (Niloff et al., 1984; Halila et al., 1986), it was of interest to see if CA 125 could be of any help in the diagnosis and follow-up of ectopic pregnancies (if they induce a peritoneal irritation) and if the clinical usefulness was similar to PAPP-A measurements.

\section{Patients and methods}

Blood samples ( $n=159$ ) collected onto ethylene-diamine tetraacetic acid (EDTA) were obtained at various periods of time [10-40 days from embryo transfer (ET)] in 39 women with a positive pregnancy test following IVF and ET. Follicular maturation was induced by a protocol which has already been described (Zorn et al., 1988). When oestradiol levels were $>1000 \mathrm{pg} / \mathrm{ml}$ and when at least two follicles $>15 \mathrm{~mm}$ could be seen at ultrasound, ovulation was induced by $5000 \mathrm{IU}$ of human chorionic gonadotrophin (HCG). Oocytes were collected $36 \mathrm{~h}$ after induction and fertilization occurred in vitro in medium B2 (Menezo, Abisystem France). Embryos (one to five) were re-implanted $48 \mathrm{~h}$ later and HCG (1500 IU) was given 1 and/or 3 or 5 days post-ET. The patients were followed thereafter by ultrasound. The day of ET was considered to be day 0 of pregnancy. 


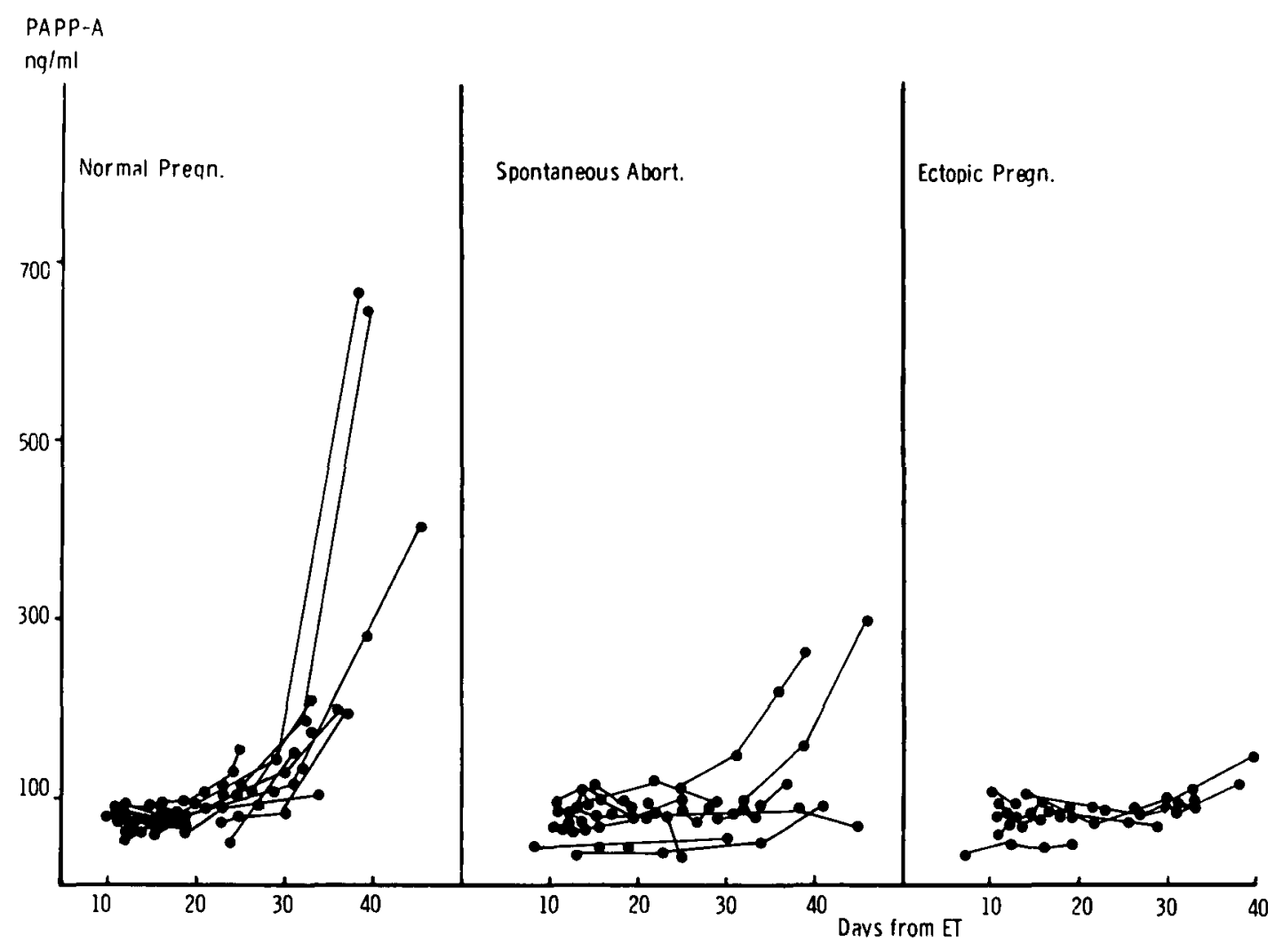

Fig. 1. Individual PAPP-A values according to the outcome of pregnancy.

Table I. PAPP-A and CA 125 concentrations according to the type of pregnancy and time after ET

\begin{tabular}{|c|c|c|c|c|c|c|c|c|}
\hline & \multirow[t]{2}{*}{$\begin{array}{l}\text { Non-pregnant } \\
\text { controls }\end{array}$} & \multicolumn{3}{|c|}{$\begin{array}{l}\text { PAPP-A } \mathrm{ng} / \mathrm{ml} \pm \mathrm{SEM} \\
(n)\end{array}$} & \multirow[t]{2}{*}{$\begin{array}{l}\text { Non-pregnant } \\
\text { controls }\end{array}$} & \multicolumn{3}{|c|}{$\begin{array}{l}\mathrm{CA} 125 \mathrm{U} / \mathrm{ml} \pm \mathrm{SEM} \\
(n)\end{array}$} \\
\hline & & $<20$ days & $21-30$ days & $31-40$ days & & $<20$ days & $21-30$ days & $31-40$ days \\
\hline Normal pregnancy & & $\begin{array}{l}75.0 \pm 1.6^{\mathrm{a}} \\
(36)\end{array}$ & $\begin{array}{l}130.4 \pm 4.8^{\mathrm{b}} \\
(19)\end{array}$ & $\begin{array}{l}279.2 \pm 69.2 \\
(10)\end{array}$ & & $\begin{array}{l}164.3 \pm 25.5^{f} \\
(26)\end{array}$ & $\begin{array}{l}1527 \pm 36.7 \\
(18)\end{array}$ & $\underset{(8)}{60.4 \pm 20.1^{8}}$ \\
\hline $\begin{array}{l}\text { Normal pregnancy } \\
\text { with hyperstimulation }\end{array}$ & $(5)$ & $\begin{array}{l}83.0 \pm 6.0 \\
(5)\end{array}$ & (1) & & & $\begin{array}{l}3683.8 \pm 360.2^{h} \\
(5)\end{array}$ & & \\
\hline Abortion & & $\begin{array}{l}79.0 \pm 2.6 \\
(28)\end{array}$ & $\begin{array}{l}85.6 \pm 2.9^{c} \\
(17)\end{array}$ & $\begin{array}{l}129.3 \pm 22.3^{\mathrm{d}} \\
(9)\end{array}$ & & $\begin{array}{l}115.8 \pm 19.0 \\
(23)\end{array}$ & $\begin{array}{l}116.7 \pm 32.3 \\
(12)\end{array}$ & ${ }_{(7)}^{88.4 \pm 25.3}$ \\
\hline Ectopics & & $\begin{array}{l}80.8 \pm 4.4 \\
(6)\end{array}$ & $\begin{array}{l}80.8 \pm 56 \\
\text { (4) }\end{array}$ & $\begin{array}{l}97.7 \pm 10.4 \\
(3)\end{array}$ & & ${ }_{(5)}^{71.2} \pm 10.0^{1}$ & $(4) \quad 39.3 \pm 5.9$ & (3) $19.3 \pm 4.8^{h}$ \\
\hline
\end{tabular}

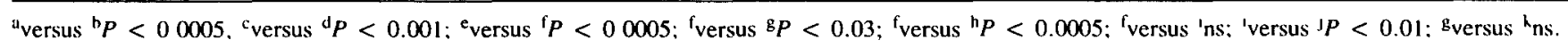

In addition, EDTA plasma was obtained during the luteal phase (days 19-25) from 13 normal volunteers with regular cycles. None was under hormonal therapy. These women served as a control group.

PAPP-A was measured by radioimmunoassay according to a method published elsewhere (Bischof et al., 1981; Bischof and Meisser, 1989). CA 125 measurements were performed with a commercially available immunoradiometric assay (Centocor CA $125^{\mathrm{TM}}$, Medipro AG, Teufen, Switzerland). Results were ranked according to the length of gestation and according to the outcome of pregancy: normal pregnancy ( $n=21,72$ samples), first trimester abortions ( $n=12,54$ samples) and ectopic pregnancy ( $n=6,33$ samples). No samples were available after spontaneous abortion had occurred. 


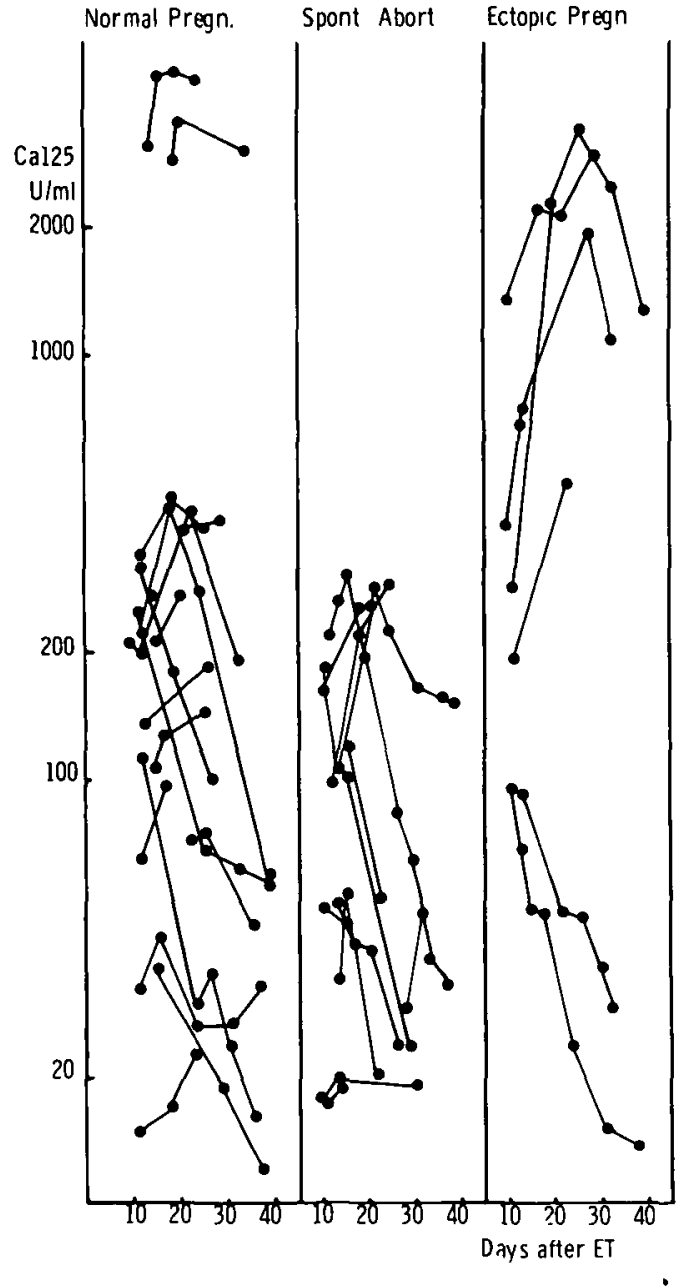

Fig. 2. Individual CA 125 values according to the outcome of pregnancy.

Statistical analysis was performed by computer using the SPSS (Statistical Package for Social Sciences) program. Regression analysis and Student's $t$-test for paired or unpaired variables were used when appropriate, and the median and 10th and 90th percentiles calculated from the group of normal pregnant patients. Diagnostic parameters (sensitivity, specificity and predictive value) were calculated for $C A 125>90$ th percentile and for PAPP-A < 10th percentile according to an established method (Galen and Gambino, 1975).

\section{Results}

Individual values of PAPP-A for all three groups of pregnancies are shown in Figure 1. Irrespective of the type of pregnancy eventually diagnosed (normal, spontaneous abortion or ectopic pregnancy), the levels of PAPP-A remained low and unchanged up to $25-28$ days after ET. After 30 days all nine patients, for whom blood was available and who experienced a normal pregnancy, had increased levels of PAPP-A (compared with nonpregnant controls; Figure 1, Table I). Only two out of six patients who spontaneously miscarried and for whom samples were available after 30 days showed an increase in PAPP-A after 30 days (Figure 1). None of the five patients (with blood samples
Table II. Clinical details about the six cases with peritoneal irritation

\begin{tabular}{llll}
\hline Patient & Diagnosis & $\begin{array}{l}\text { Day of } \\
\text { diagnosis } \\
\text { from E' }\end{array}$ & $\begin{array}{l}\text { First high } \\
\text { value of CA125 } \\
\text { days from ET }\end{array}$ \\
\hline $1 \quad \begin{array}{l}\text { Normal pregnancy, hyperstımulation } \\
\text { at US }\end{array}$ & 2 & $14^{\mathrm{h}}$ \\
2 & $\begin{array}{l}\text { Normal pregnancy, hyperstımulation } \\
\text { and ascites, US and clinical signs }\end{array}$ & 12 & $19^{\mathrm{b}}$ \\
3 & $\begin{array}{l}\text { Suspicion of ectopic preganncy at US } \\
\text { Salpingitis diagnosed at surgery }\end{array}$ & 14 & 10 \\
4 & $\begin{array}{l}\text { Ruptured ectopic pregnancy, } \\
\text { blood collection }\end{array}$ & 23 & 12 \\
5 & $\begin{array}{l}\text { Suspicion of ecotpic pregnancy at US } \\
\text { Hydrosalpinx at surgery }\end{array}$ & 36 & 11 \\
6 & $\begin{array}{l}\text { Suspicion of ectopic pregnancy at US } \\
\text { Ruptured ectopic pregnancy at surgery }\end{array}$ & 40 & 11 \\
\hline
\end{tabular}

${ }^{a}$ Ultrasound

${ }^{\text {b }}$ No blood samples were available before.

after 30 days) in whom an ectopic pregnancy was diagnosed had an increase in PAPP-A (Table I).

Individual CA 125 values are shown in Figure 2. High CA 125 levels were observed in all groups between 10 and 20 days after ET. After 20 days, the levels decreased in normal pregnancies and in the group of spontaneous abortions, whereas only two out of six patients with ectopic pregnancies showed a decrease in CA 125. Two patients with normal pregnancies and four patients with ectopic pregnancies had very high levels of CA 125 throughout the observation period. All these patients showed, at one time or another, clinical and/or ultrasound signs of peritoneal irritation (Table II), due either to hyperstimulation (two cases of normal pregnancy) or to ruptured ectopic pregnancy (two cases), to hydrosalpinx (one case) or to salpingitis (one case). In the four cases of ectopic pregnancy, high CA 125 levels were recorded 4-30 days before the pathology could be diagnosed (Table II). In the two cases of normal pregnancy, no blood samples were available before the date of diagnosis of hyperstimlation.

A further evalution was performed by ranking the $C A 125$ and PAPP-A values according to the type of pregnancy and according to the length of gestation (Table I).

In normal pregnancies and up to 20 days after ET, the levels of PAPP-A were similar to the non-pregnant controls. However, PAPP-A was significantly $(P<0.0005)$ increased in the groups of 21-23 days and 31-40 days. The mean time at which PAPP-A was found to be significantly higher than the non-pregnant controls ( $>$ mean $+2 \mathrm{SD}$ ) was $27.2 \pm 1.1$. day (mean \pm SEM, $n=14$ ). In the group of spontaneous abortions, PAPP-A levels remained comparable to the non-pregnant group up to 30 days and increased significantly thereafter $(P<0.01)$ to levels which were about half of those in normal pregnancies. No significant increase was seen in ectopics either with or without peritoneal irritation, so that the concentrations of PAPP-A remained at the level of non-pregnant controls up to 40 days after ET. 
Table III. Diagnostic parameters of CA 125 and PAPP-A in ectopic pregnancies and/or spontaneous abortions

\begin{tabular}{|c|c|c|c|}
\hline & $\begin{array}{l}\text { Period of } \\
\text { gestation } \\
\text { (days) }\end{array}$ & $\begin{array}{l}\text { Detection of } \\
\text { ectopics if } \\
\text { CA } 125>90 \text { th centule }\end{array}$ & $\begin{array}{l}\text { Detection of ectopics or } \\
\text { spontaneous abortions if } \\
\text { PAPP.A }<10 \text { th centile }\end{array}$ \\
\hline $\begin{array}{l}\text { Sensitivity } \\
\text { of the tests }\end{array}$ & $\begin{array}{l}<20 \\
21-30 \\
31-40\end{array}$ & $\begin{array}{l}50 \\
667 \\
500\end{array}$ & $\begin{array}{c}0 \\
35.3 \\
87.5\end{array}$ \\
\hline $\begin{array}{l}\text { Specifity } \\
\text { of the tests }\end{array}$ & $\begin{array}{l}<20 \\
21-30 \\
31-40\end{array}$ & $\begin{array}{l}86.2 \\
86.4 \\
75.0\end{array}$ & $\begin{array}{l}94.7 \\
100 \\
100\end{array}$ \\
\hline $\begin{array}{l}\text { Predictive value for } \\
\text { the disease }\end{array}$ & $\begin{array}{l}<20 \\
21-30 \\
31-40\end{array}$ & $\begin{array}{l}42.9 \\
57.1 \\
400\end{array}$ & $\begin{array}{r}0 \\
100 \\
100\end{array}$ \\
\hline $\begin{array}{l}\text { Predictive value for } \\
\text { absence of disease }\end{array}$ & $\begin{array}{l}<20 \\
21-30 \\
31-40\end{array}$ & $\begin{array}{l}89.3 \\
90.5 \\
81.8\end{array}$ & $\begin{array}{l}50.0 \\
57.7 \\
88.9\end{array}$ \\
\hline
\end{tabular}

"All measured values were considered in the calculation and not only one per patient.

CA 125 levels in normal pregnancies were significantly higher $(P<0.0005)$ than in non-pregnant controls throughout the entire obscrvation period (10-40 days after ET). However, they were significantly $(P<0.0005)$ lower between 31 and 40 days than before. In normal pregnancies with hyperstimulation, the concentrations of CA 125 were $\sim 20$ times higher than in normal pregnancies without hyperstimulation (Table I). Spontaneous abortions and ectopic pregnancies without peritoneal irritation had CA 125 levels which were not statistically different from ongoing pregnancies. In ectopic pregnancies with peritoneal irritation, the levels of CA 125 were 15-50 times higher than in ectopic pregnancies which had no signs of peritoneal irritation (Table I).

Table III gives the diagnostic parameter for ectopic pregnancies and spontaneous abortions if PAPP-A $<10$ th percentile. The diagnostic potency of these tests depended on the duration of pregnancy: the sensitivity of PAPP-A $<10$ th percentile was acceptable for pregnancies of $>30$ days from ET but not before (Table III). The first values of PAPP-A $<10$ th centile were observed between days 29 and 33 of pregnancy. Under these conditions, the specificity and predictive value for the disease were $100 \%$, whereas the predictive value for the absence of the disease was $88.9 \%$. The diagnostic parameters for CA 125 were not as good as those for PAPP-A (Table I). The predictive value for the disease was between 40 and $57 \%$ depending on the duration of pregnancy. The specificity and sensitivity were also poor. However, the predictive value for absence of disease was acceptable $(81.8-90.5 \%)$.

\section{Discussion}

Several pregnancy proteins have been evaluated in the search for a specific biochemical marker of ectopic pregnancy. PAPP-A is certainly the most promising, since several studies reported depressed or even undetectable PAPP-A levels in women with established ectopic pregnancies (Grudzinskas et al., 1984; Sjöberg, 1987; Tornehave et al., 1987). In asymptomatic patients after IVF-ET (Sinosich et al., 1983, 1985), it was reported that in threatened abortions in the presence of a live fetus, PAPP-A levels were consistently depressed and that the sensitivity of such a test was $91.7 \%$ (Sinosich et al., 1985). In the present study using a similar design (samples collect prospectively but earlier on a larger group of 39 consecutive asymptomatic patients), we obtained a sensitivity of $87.5 \%$ for PAPP-A levels being below the 10 th percentile in pregnancies between 30 and 40 days after ET. Before 30 days, PAPP-A measurements are not useful. Despite the fact that with this test, no distinction can be made between ectopic pregnancies and intra-uterine abortions, PAPP$A$ is certainly an excellent parameter by which to monitor postimplantation viability of embryos. In the present study, and in contrast to other studies (Grudzinskas et al., 1984; Sjöberg, 1987; Tornehave et al., 1987), PAPP-A levels were depressed in ectopic pregnancies but never below the sensitivity of the assay and were even measurable in non-pregnant women. As reported recently (Bischof and Meisser, 1989), this difference is due to the immunological heterogeneity of PAPP-A and to the fact that we use EDTA plasma samples and standards.

When compared with non-pregnant controls, CA 125 levels were reported to be significantly higher during the first trimester of pregnancy but not thereafter (Niloff et al., 1984; Halila $e t$ al., 1986; Seki et al., 1986). In early pathological pregnancies, CA 125 measurements have not heretofore been reported. In the present study, CA 125 levels were significantly increased during early normal and pathological pregnancy. In the group of patients ending their pregnancy by a spontaneous abortion, the levels of CA 125 were similar to normal pregnancies. However, whenever signs of peritoneal irritations were present (hyperstimulation in normal pregnancies or ruptured ectopic pregnancies), the values of CA 125 were dramatically increased days before the pathology was evident. Increased CA 125 levels, however, have no diagnostic value for ectopic pregnancies, since normal values can be found in this group (those without peritoneal irritation) and increased values were found in normal pregnancy with hyperstimulation. A very high level of CA 125 in early 
pregnancy, either in normal or in pathological pregnancies (before 30 days from ET), is thus only indicative of peritoneal inflammation. This raises the question of the origin of CA 125 . We have produced evidence in vitro (Bischof et al., 1986) that CA 125 could be produced by the endometrium, thus providing an explanation for the increased CA 125 levels during endometriosis. The present observations, however, tend to attribute the origin of CA 125 in pregnant women to the fetus and/or to the peritoneal wall, an observation which would fit with the tissue distribution of CA 125 as reported by Kabawat $e t$ al. (1983).

\section{Acknowledgements}

The authors wish to express their gratitude to Mrs C.Gruffat and M. Mendez for their skilful assistance and Drs P.Boyer, A.Guichard and J.R.Zorn for access to the patients of the IVF Centre Baudelocque-SaintVincent-de-Paul. We also thank Mrs I.Riederer for typing the manuscript.

\section{References}

Bast,R.C., Fenney,M., Lazarus,H., Nadler,I.M., Colvin,B.B. and Knapp,R.C. (1981) Reactivity of a monoclonal antibody with human ovarian carcinoma. J. Clin. Invest., 68, 1331-1337.

Bast,R.C., Klug,T.L., St John E., Jenisson,E., Niloff,J.M., Lazarus,H., Berkowtiz,R.S., Laevitt,T., Griffith,C., Parker,L., Zurawski,V. and Knapp,R.C. (1983) A radioimmunoassay using a monoclonal antibody to monitor the course of epithelial ovarian cancer. N. Engl. J. Med., 309, $169-171$.

Bischof,P. and Meisser,A. (1989) Immunological heterogeneity of pregnancy-associated plasma protein-A (PAPP-A). Effects on the radioimmunoassay of PAPP-A. Br. J. Obstet. Gynaecol., in press.

Bischof,P., Haenggeli,L., Sizonenko,M.T., Herrmann,W.L. and Sizonenko,P.C. (1981) A radioimmunoassay for the measurement of pregnancy-associated plasma protein-A (PAPP-A) in humans. Biol. Reprod., 24, 1076-1081.

Bischof,P., DuBerg,S., Herrmann,W. and Sizonenko,P.C. (1982) Amniotic fluid and circulating levels of pregnancy-associated plasma protein-A (PAPP-A) throughout pregnancy. Comparison with other foeto-placental products. Br. J. Obstet. Gynaecol., 89, 358-363.

Bischof,P., Reyes,H., Herrmann,W.L. and Sizonenko,P.C. (1983) Circulating levels of pregnancy-associated plasma protein-A (PAPPA) and hCG in intra-uterine and extra-uterine pregnancies. Br. $J$. Obstet. Gynaecol., 90, 323-325.

Bischof,P., Tseng,L., Brioschi,P.A. and Herrmann,W.L. (1986) Cancer antigen 125 is produced by human endometrial stromal cells. Hum. Reprod., 1, 423-426.

Brioschi,P.A., Irion,O., Bischof,P., Bader,M., Fornı,M. and Krauer,F. (1987) Serum CA 125 in epithelial ovarian cancer. A longitudinal study. Br. J. Obstet. Gynaecol., 94, 196-201.

Folkersen,J., Grudzinskas,J.G., Hindersson,P., Teisner,B. and Westergaard,J.G. (1981) Pregnancy-associated plasma protein-A: circulating levels during normal pregnancy. Am. J. Obstet. Gynecol., 139, 910-914.

Galen,R.S and Gambino,S.R. (1975) Sensitivity, specificity, prevalence and incidence. In Galen,R.S. and Gambino,S.R. (eds), Beyond Normality: the Predictive Value and Efficiency of Medical Diagnosis. John Wiley \& Sons, Sydney, p. 10.

Grudzinskas,J.G., Westergaard,J.G. and Teisner,B. (1984) Pregnancyassociated plasma protein-A in normal and abnormal pregnancies. In Bischof,P. and Klopper,A. (eds), Proteins of the placenta, Sth International Congress on Placental Proteins. Karger, Basel, p. 184-197.

Halila,H., Stenman,U.H. and Seppälä,M. (1986) Ovarian cancer antigen
CA 125 levels in pelvic inflammatory disease and pregnancy. Cancer, 57, $1327-1329$.

Kabawat,S.E., Bast,R.C., Bhan,A.K., Welch,W.R., Knapp,R.C. and Colvin,R.B. (1983) Tissue distribution of a coelomic-epitheliumrelated antigen recognized by the monoclonal antibody OC $125 . \mathrm{mt}$. J. Gynecol. Pathol., 2, 275-285.

Niloff,J.M., Knapp,R.C., Schaetzl,E., Reynolds,C. and Bast,R.C. (1984) CA 125 antigen levels in obstetric and gynecologic patients. Obstet. Gynecol., 64, 703-707.

Seki,K., Kikuchi,Y., Uesato,T. and Kato,K. (1986) Increased serum CA 125 levels during the first trimester of pregnancy. Acta Obstet. Gynecol., 65, 583-586.

Sinosich,M.J., Davey,M.W., Ghosh,P. and Grudzinskas,J.G. (1982) Specific inhibition of human granulocyte elastase by human pregnancyassociated plasma protein-A. Biochem. Int. , 5, 777-786.

Sinosich,M.J., Smith,D.H., Grudzinskas,J.G., Saunders,D.M., Westergaard,J.G. and Teisner,B. (1983) The prediction of pregnancy failure by measurement of pregnancy-associated plasma proteinA (PAPP-A) following in vitro fertilization and embryo transfer. Fertil. Steril., 40, 539-541.

Sinosich,M.J., Ferrier,A. and Saunders,D.M. (1985) Monitoring of postimplantation embryo viability following successful in vitro fertilization and embryo transfer by measurement of placental proteins. Ferill. Steril., 44, 70-74.

Sjöberg,J. (1987) Pregnancy-associated plasma protein-A in pregnancy related gynecologic emergency. Hum. Reprod., 2, 615-616.

Stabile,I., Grudzinskas,J.G. and Chard,T. (1988) Clinical applications of pregnancy protein estimations with particular reference to pregnancy-associated plasma protein-A (PAPP-A). Obstet. Gynecol. Survey, 43, 73-82.

Tornehave,D., Chemnitz,J., Westergaard,J.G., Teisner,B., Poulsen,H.K., Bolton,A.E. and Grudzinskas,J.G. (1987) Placental proteins in peripheral blood and tissues of ectopic pregnancies. Gynecol. Obstet. Invest., 23, 97-102.

Westergaard,J.G. (1987) Studies on pregnancy-associated plasma proteinA (PAPP-A) in normal and abnormal pregnancy. M.D. Thesis. University of Odense, Denmark.

Zorn,J.R., Barata,M., Brami,C. Epelboin.S., Nathan,C., Papageorgiou,G., Quantin,P., Rolet,F., Savale.M., Boyer,P., Guichard,A., Cédard,L., Comaru-Shally,A.M. and Schally,A.V. (1988) Ovarian stimulation for in-vitro fertilization combining administration of gonadotrophins and blockade of the pituitary with D-Trp ${ }^{6}$-LHRH microcapsules: pilot studies with two protocols. Hum. Reprod., 3, 235-238.

Received on April 24, 1989; accepted on May 26, 1989 